Sassòli, Marco 2006: Transnational Armed Groups and International Humanitarian Law, Occasional Paper Series, Program on Humanitarian Policy and Conflict Research, Harvard University, Number 6.

Hofmann, Claudia/Schneckener, Ulrich 2010: Verhaltensänderung durch Normdiffusion? Die Ansätze von IKRK und Geneva Call im Umgang mit bewaffneten Gruppen, in: Die Friedens-Warte, 85, 4, 73-98. SPLM/A 2001: Statement of the Sudan People' Liberation Movement/Army on the Occasion of the Signing and Depositing to Geneva Call Deed of Commitment to Ban Landmines, 4. Oktober 2001, www.genevacall.org/resources/ nsas-statements/f-nsas-statements/2001-2010/2001-04octsplma.htm, 6.1.2010.

United Nations 2009: Honoring Geneva Conventions, Secretary-General Says Debate 'No Longer between Peace and Justice but between Peace and What Kind of Justice', UN Press Release SG/SM/12494, New York.

\title{
Hezbollah's Rise and Decline? How the Political Structure Seems to Harness the Power of Lebanon's Non-State Armed Group
}

\author{
Eva Dinge ${ }^{*}$
}

\begin{abstract}
In this article I will discuss the transformation from non-state armed group to governing party that the Lebanese Hezbollah has undergone since 2005. The 'hard facts' suggest a success story: the Shiite party has participated in various governments since 2005, brought down the cabinet in 2011, and controlled the formation of a new government. This has sparked widespread fears of an Islamist takeover of power in Lebanon. When we take a broader perspective, however, a different picture emerges: Hezbollah is more dependent on being part of the Lebanese political structure than its rhetoric would suggest or many observers assume. Participation in politics provides the group with much-needed legitimation as a democratic, civil actor, and shields it to some extent from international pressure to disarm. As long as it was enjoying full Syrian support and backing, Hezbollah has not hesitated to challenge the political status quo and risk political breakdown. However, since the beginning of the uprising in Syria, the party has had to tread more carefully. This explains why, since it brought down the Lebanese government in 2011, Hezbollah has largely played by the rules of the political game.
\end{abstract}

Keywords: Hezbollah, non-state armed group, Lebanon, Syria Hisbollah, nicht-staatliche bewaffnete Akteure, Libanon, Syrien

$\mathrm{E}$ ver since Hezbollah forced the resignation of Prime Minister Saad al-Hariri in January 2011 and was instrumental in influencing the make-up of the successor cabinet headed by Najib al-Mikati, the Islamist party-cum-militia is regarded as Lebanon's most powerful political player. As Hezbollah is a religious party and has embraced an agenda aimed at achieving social change, expectations that it would implement such changes after practically taking over power in Lebanon were high. This has been widely connected with fears of an Islamist takeover in Lebanon, the institution of religiously inspired policies, and generally a profound transformation of politics in Lebanon. At the time of writing, in January 2013, none of this has actually transpired. Instead, politics in Lebanon throughout the past two years, as tumultuous as it has been, has largely been "business as usual," in the sense that despite ongoing political conflict and crises, the nature of the political system has remained the same. Why have the expectations of change that Hezbollah's rise in political power had created not come true? I will argue that this is partly the result of the predominance

Eva Dingel is currently studying for a PhD at the Otto-Suhr-Institute at Free University Berlin. She is working on the topic of political strategies of Hezbollah and the Egyptian Muslim Brotherhood. of political structure over agency, and partly determined by the regional political situation and the party's implication in the assassination of former Prime Minister Rafik Hariri.

\section{Hezbollah's Hybrid Nature: Non-State Armed Group, Social Movement, Political Party}

Hezbollah, literally 'Party of God', was formed in Lebanon's Beqaa valley from 1982 onwards with Iranian support. Its formation was largely a response to Israel's invasion of South Lebanon the same year (for accounts of Hezbollah's foundation, see Aboul-Enein 2005; Alagha 2006; Hamzeh 2004; Norton 2009; Ollaik and Najjar 2012; Palmer Harik 2007; Qassem 2005; Saad-Ghorayeb 2002; Samaan 2007). The political domain and the military were intricately connected from the first days and months of Hezbollah's existence. The new organization also quickly set up various charities, which have bloomed into a comprehensive network of social-service providers (Deeb 2006; Hamzeh 2004, 52-3). When Lebanon's 15-year civil war (1975-1990) finally drew to an end, Hezbollah was the only wartime armed actor allowed to hold on to its weapons arsenal. All other militias were required to lay down 
their arms and transform into civil political actors. This special status was justified by reference to the continuing Israeli occupation of a "security zone" in South Lebanon. Hezbollah assumed the responsibility of freeing Lebanese territory from foreign occupation, a task that the other political actors in the country agreed to delegate to the non-state actor and in fact were powerless to argue against. Syria had assumed political dominance over Lebanon in the wake of the civil war, an arrangement that was widely accepted for it guaranteed stability in Lebanon as part of a Pax Syriana (Hinnebusch 1998). Syria maintained close relations with Hezbollah, and the party quickly came to be regarded as Syria's proxy in Lebanon.

After a number of military confrontations with Hezbollah and a drawn-out war of attrition, Israel finally withdrew all forces from South Lebanon in 2000. This was naturally celebrated by Hezbollah as a major victory against one of the most powerful armies in the world. In parallel, Hezbollah also became a fixture in Lebanese politics after deciding to take part in the first post-war parliamentary elections in 1992, and continuing to do so since. The party's entry into the Lebanese political system provided it with a number of benefits: access to state resources, a forum to express its views and ideas, as well as additional legitimation as an official political party. This came to be more important after Israel withdrew and the previous justification for Hezbollah's arms, i.e. that they were necessary to liberate Lebanese territory, was no longer a given. Its double status as political party and armed group was helpful in preventing others from labeling it as merely a militia or terrorist group that refused to give up its weapons.

\section{Power-sharing Conflicts after the Syrian Withdrawal in 2005}

A landmark event for Hezbollah's - as well as Lebanon's recent political history was the assassination of former Prime Minister Rafik Hariri in February 2005. He had served as Lebanon's Prime Minister for the majority of the post-civil war period and had long maintained a good working relationship with the Syrian regime, but was assassinated a few months after he had fallen out with it and resigned. An International Investigation Commission was set up by the United Nations in 2005 in order to look into the assassination, initially suspecting the Syrian leadership of involvement in Hariri's murder. The ensuing international and domestic pressure forced Syria to withdraw its forces from Lebanon in April 2005, leading to a reshuffling of political cards. These changes had a number of consequences: Lebanon became openly divided into two political camps, termed March 14 (anti-Syrian) and March 8 (pro-Syrian). ${ }^{1}$ The March 14 grouping is supported by

1 The names derive from two massive demonstrations. Both were held in central Beirut following the assassination of Rafik Hariri. One, held on March 8, supported the Syrian regime and its presence in Lebanon, and was composed of supporters of all pro-Syrian parties in Lebanon: Hezbollah, Amal, the Syrian Socialist National Party, the Arab Democratic Party, and a number of others. The one held on March 14 brought together the opponents of a Syrian presence in Lebanon and called for a withdrawal of Syrian forces from Lebanon. The alliance of political parties that subsequently adopted the name 'March 14' for itself is composed of the Sunni Future Movement, the Lebanese Forces, and a number of other mostly Christian political parties who had previously been opponents of Syria. the United States as well as most European countries, while March 8 is backed by Syria and Iran. With Syria gone from Lebanon, pressure on Hezbollah increased: a U.S.-sponsored UN Resolution called for the party's disarmament. The UN investigation into Hariri's murder increasingly began to focus on Hezbollah's possible involvement. Hezbollah responded to the pressure by vehemently opposing the ratification of the statutes for a UN Special Tribunal for Lebanon (STL), and deploying the withdrawal of government ministers, street demonstrations, a general strike (all in 2006-2007), armed clashes with March 14 supporters (in 2008) and political threats and negotiations (2009-2010) in order to prevent this. It eventually failed and the Tribunal was set up in 2009.

\section{Hezbollah Brings Down the Government and Sets up Another: 2010-2012}

As the preceding discussion has shown, Hezbollah has managed to become a key political player on Lebanon's domestic scene. It has become part of the post-civil war political game, which is premised on a general consensus between the major players. As soon as this consensus breaks down, the system stops functioning altogether and a deep governmental crisis ensues, which is either resolved by international mediation or by way of a national dialogue. Whenever Hezbollah has enjoyed a position of strength relative to its political rivals in Lebanon, it has not hesitated to cause a breakdown of the system: this was the case in 2006, 2007 and 2008. When the party started gradually losing its position of strength from 2011 onwards - because Syria became embroiled in a civil war, Hezbollah was siding with it and losing credibility for doing so, and the STL issued indictments of Hezbollah members - it generally played along with the rules of Lebanon's political game and refrained from causing a breakdown. This is best illustrated by the Lebanese government's decision to keep funding the STL, taken at the end of 2011 over Hezbollah's objections. In this section, I will discuss in detail the events and conflicts leading up to this decision, and also look beyond it to the developments in 2012.

In December 2010, reports were leaked to the press that the Special Tribunal for Lebanon had drawn up a bill of indictment and that it was likely to name Hezbollah members. Hezbollah tried to convince the government of Prime Minister Saad Hariri to renounce the indictment of Hezbollah as an organization, as well as of individual Hezbollah members. Having him, as the son and political heir of Rafik Hariri, personally do so would have taken a lot of pressure off Hezbollah and effectively eliminated the political threat emanating from the tribunal. In order to avert renewed outbreaks of political violence over this issue, there was a Saudi-Syrian mediation effort that sought to bridge the gap between the Lebanese government and the opposition led by Hezbollah, and which put forward three key demands:

- Lebanon should end its financial support to the tribunal

- It should withdraw all Lebanese judges on the tribunal

- And finally, it should annul the treaty of cooperation with the tribunal 
This political move on behalf of two major regional states, one backing the current government majority (Saudi-Arabia), the other backing the opposition and Hezbollah (Syria), is in itself remarkable for its willingness to question the rule of international law in order to offer a face-saving solution to Lebanese actors. On the other hand, it was always clear that even if these demands had been achieved, the tribunal could have gone on functioning - its funding was secured, the withdrawal of Lebanese judges would not have impeded its work, and even the annulment of the cooperation treaty would not have had major consequences, as the tribunal had been established under Chapter VII and was thus not dependent on Lebanese cooperation (Muhanna 2011). Had Hariri accepted these demands, the opposition would have supported him as Prime Minister. When he turned down the initiative, however, the ministers of all opposition parties collectively resigned from the cabinet, bringing down the government on January 12, 2011.

The subsequent flurry of international mediation activity demonstrates that many Arab and European countries were extremely concerned that the political situation in Lebanon might spin out of control. Efforts to revive the Saudi-Syrian initiative continued and were soon joined by Qatar, which had already hosted negotiations that produced the 2008 Doha Agreement. When Saudi-Arabia declared it was withdrawing from mediation efforts in Lebanon because developments were becoming too "dangerous", Turkey became involved and the Qatari and Turkish foreign ministers - apparently with the blessing of French President Nicolas Sarkozy - met with Lebanese political leaders of both sides in Beirut in January 2011. Meanwhile, there were reports of Hezbollah and Amal youths demonstrating in the streets, and the general climate was one of extreme apprehension. The renewed mediation efforts did not succeed, and soon Hezbollah announced it would back the candidacy of Najib Mikati, a Sunni businessman from Tripoli, for the post of Prime Minister. Mikati had already briefly held this post after the assassination of the elder Hariri in 2005. With this nomination, it became clear that there was no consensus between Hezbollah and the government, and that both sides would seek to promote their own candidate. Hezbollah and its political partners were eventually helped by the fact that the Progressive Socialist Party headed by Druze leader Walid Jumblatt changed sides and defected from March 14 to join forces with March 8, affording the latter the necessary majority to form a new cabinet.

Lebanese President Michel Sleiman eventually called on Najib Mikati to form and head the new government, signaling the opposition's victory. Hezbollah Secretary-General Hassan Nasrallah immediately went on television to assure the public that the new government would be based on consensus, that it would be a "partnership government" that would never seek to exclude any particular group (i.e., the March 14 bloc) from power. In a subsequent speech, he also insisted that the new government was not a "Hezbollah government", and that Mikati was not a puppet of Hezbollah. This message was not heard by March 14 supporters, who took to the streets in a "day of rage" after Mikati's nomination to the post of Prime Minister. Bloody clashes took place in Tripoli, hometown of
Mikati and host to divided groups of March 8 and March 14 supporters.

Meanwhile, different groups within March 14 had different views on the issue, with some refusing to participate in a government whose terms were perceived to be dictated by Hezbollah and March 8. Others were in favor of participating. In mid-February 2011, it became public that Hezbollah had demanded of Mikati to drop any reference to the STL from his inaugural policy statement for the new government. In a February 18 speech, Hezbollah Secretary-General Hasan Nasrallah accused the STL of being a political investigation and of being "unable to lead to justice." He also reaffirmed Hezbollah's intention to retain its arms and expressed a lack of understanding for the repeated call to disarm, since the formula of the "people, the army and the resistance are one" had been part of the Lebanese government's policy statement already in 2009. The adoption of this statement signaled a significant political victory for Hezbollah, as it constituted an official government recognition of Hezbollah's armed status. He went on to say that Najib Mikati was in no way affiliated with Hezbollah and possessed an independent mind, pursuing his own independent agenda. He accused the "other team" (i.e., Hariri's Future Movement and March 14) of politicizing this issue in order to bring U.S. and European pressure to bear on the new, presumed "Hezbollah" government of Lebanon.

Inside Lebanon, Hezbollah's reconciliatory rhetoric about a 'unity' or 'cooperation government' was not taken seriously by its political rivals of the Future Movement. Minister of the Economy Mohammad Rahhal, a member of the movement, declared in the wake of Nasrallah's speeches that "we have extended our hand to them (i.e. to Hezbollah, this author), and they have stabbed us in the back". More forcefully, Saad Hariri, in February 2011 still caretaker Prime Minister of Lebanon, expressed the disappointment felt by many in the Future Movement and March 14 camp when he said in a speech marking the anniversary of his father's assassination (Lebanese National News Agency 2011b):

"Therefore, I come back to you to say clearly that the supremacy of weapons over political and cultural life in Lebanon is the problem - I repeat the problem - that prevents the regularization of public life in our country. Some said weapons are a detail and the problem is resistance; namely, we have a problem with resistance against Israel. We say clearly: No, the problem is not resistance against a non-Lebanese and a non-Arab external enemy, that is, Israel, which is our only enemy. The problem is with the supremacy of weapons over your Lebanese Arab brothers and over life in Lebanon. The problem is when you say that these weapons will not be used at home, and then we find that these weapons have been used only at home since the 'glorious day' on 7 May 2008 [when Hezbollah supporters clashed with government]. (sic) How can we forget 'the glorious day,' the day of bullying in Beirut and the mountain against the people of Beirut and the mountain? The problem is that you said before the last parliamentary elections that you would not enter the government if you lost the elections. You lost them and said: 'Let none think of a government in which we do not have a blocking third. 
Otherwise, weapons will be ready to be used against the people of your country.'"

This clearly expresses the politically divisive nature of Hezbollah's insistence on holding on to its military arsenal or its "weapons," as they are commonly referred to in Lebanon. The whole political scene of the country remained divided into two camps, March 8 and March 14, as it had been since 2005. Instead of the distance lessening, however, the gulf only widened as time went on, especially after the civil war-like fighting of May 2008. Hariri's words show the link that other actors in Lebanon see between Hezbollah's weapons and its political ambitions; in his words, Hezbollah had "lost the elections" in 2009 (while in Nasrallah's version, Hezbollah had won the "popular vote" and merely become a victim of Lebanon's skewed electoral system, which did not allot enough seats to the party and its allies to control government) and then, at the beginning of 2011, used the threat of its weapons to bring down the "national unity government" that had been formed after these elections. The March 8 camp responded to these accusations by labeling them a "rabid campaign" against Hezbollah and its allies, and calling on Lebanese Sunnis not to let the Future Movement take them hostage for its political agenda. This, once again, highlighted the sectarian nature of the conflict.

For much of the spring and summer of 2011, the government formation process was held up by the demands of Hezbollah ally Michel Aoun, who was demanding one of the key ministries, preferably that of the Interior, for himself. Mikati, however, favored the incumbent, former civil society activist Ziyad Baroud, and was supported by Lebanese president Michel Sleiman. Baroud finally resigned in mid-2011 and the dispute over the cabinet's formation was resolved. Now officially Prime Minister, Najib Mikati vowed to form a government for all Lebanese and to take on crucial social and economic issues. Immediately afterwards, the March 14 camp, having decided to stay out of the government and headed into opposition, declared the new government to be a "Hezbollah government" in which the Shi'a party was dominant. Hezbollah representatives denied these allegations, pointing to the fact - as they had done during the government formation process - that only two ministries were held by Hezbollah representatives, and to Najib Mikati being a politician in his own right who was not controlled by the party. Members of the party, however, were also on record gleefully congratulating themselves on the fact that for the first time in years the United States had exercised no influence on the process of cabinet formation in Lebanon.

These developments show how thin the ice of agreement and reconciliation was in Lebanon at the time; many regarded the newly formed government to be doomed and likely to fail. The new government was formed only after Syria gave its explicit consent to the line-up, illustrating that fact that Syrian influence in Lebanese politics still played a major role, six years after Syrian troops had been forced to withdraw from the country. Lebanese President Michel Sleiman denied any allegations that Syria had been involved in the cabinet formation, but there were numerous reports of Druze leader Walid Jumblatt visiting Damascus ahead of the government's formation and of Syria giving its consent to the new cabinet. The link between the two countries was also repeatedly demonstrated by flare-ups of violence between supporters and opponents of Syrian President Bashar al-Assad inside Lebanon. This was one of the new government's first challenges, when violence broke out in Prime Minister Mikati's hometown of Tripoli between the two sides. With heavy armed clashes between Sunni anti-Assad and Alawite pro-Assad forces on Lebanese territory, the Syrian conflict was increasingly playing out inside Lebanon, as well, and was presenting a mounting challenge to Lebanon's fragile internal peace.

The first conflict between Hezbollah and Prime Minister Mikati arose over the wording of the government's policy statement, in which Mikati, responding to considerable international pressure and in an attempt to keep the political gap in the country from widening further, wanted Lebanon's commitment to international resolutions and to the Special Tribunal explicitly mentioned. Hezbollah, on the other hand, reportedly "saw no need" to mention the Special Tribunal specifically and only wanted UNSCR $1701^{2}$ mentioned by name. In an interview with Al-Arabiya television conducted shortly after the government's formation, Mikati was keen to avoid taking sides in the March 8-March 14 dispute and delegated all confrontational decisions, such as the wording in relation to the STL in the government's policy statement, to the "National Dialogue Committee." This forum contains all of Lebanon's major political leaders and had been repeatedly convened since 2006 in order to resolve the controversial questions of Hezbollah's weapons, the Shebaa Farms in South Lebanon $^{3}$, or the status of Palestinian refugees in Lebanon. To date, the different national dialogues have not produced much of substance in the way of policy change. While being the only body that could produce consequential political change, because it contains all sides' leaders and can produce consensus decisions, the National Dialogue Committee illustrates the difficult nature of Lebanon's decision-making procedures. Objections by any side automatically produce a political stalemate that either leads to the respective decision being put on hold or to lengthy mediation efforts on the part of the Lebanese president that in most cases have also produced minimal results. From Mikati's perspective, however, referring controversial decisions to the national dialogue table was the only way of legitimizing his decisions and of avoiding to be dragged into the polarized political conflict playing itself out at the time.

Towards the end of June, the tone between the March 14 and March 8 camps was escalating once again when former Prime Minister and member of the Future Movement Fouad Siniora announced that March 14 would seek to bring down the new government and did not feel represented by it. Adding to this, the STL issued its indictments one day before

2 UN Security Council Resolution 1701 of 2006 ended the month-long war between Israel and Hezbollah and, among other things, called for a complete disarmament of all non-state actors inside Lebanon. Hezbollah had supported the resolution when it was passed, mostly for tactical reasons of ending the conflict, but has refused to abide by it and has discredited the UN and international law in general as being politically biased since then

3 Controlled by Israel, claimed by both Israel and Lebanon, and cited by Hezbollah as a major reason for retaining its weapons after Israel's withdrawal from South Lebanon in 2000 
the new government's inaugural policy statement was to be announced. This certainly did not contribute to the UN tribunal being perceived as competent and independent; that it was a 'political body' was an allegation launched repeatedly since its inception. It had been a constant companion to the tribunal ever since its first prosecutor, Detlev Mehlis, openly accused the Syrian leadership of being behind the Hariri assassination in various media without producing substantial evidence.

These developments notwithstanding, the government issued its policy statement on July 1, explicitly mentioning the need to "follow up the work of the Special Tribunal for Lebanon" and to respect international commitments and resolutions. It also vowed to fight corruption and to implement economic reforms. This intent was more or less lost in the melee of accusations surrounding the publication of the STL indictments. Hezbollah spokespersons were immediately quoted as saying that the indictments would have no repercussions for the party, were merely an addition to the thousands of unexecuted indictments and warrants in Lebanon, and concerned "low-level" members of the party only (Al-Sharq al-Awsat 2011). Moreover, the issue of the indictments was politicized, according to the same spokesperson, and the deeds of individuals were being used to accuse the whole party and blame it for the assassination of Hariri. ${ }^{4}$ The March 14 camp, on the other hand, was insistent that the STL was merely ensuring the rule of law, and that the indictments and arrest warrants had been issued against individuals, not against Hezbollah as a party. Future Movement representatives, most vitriolically among them former Prime Minister Fouad Siniora, warned the new government against disavowing the STL investigation, threatening to bring the political process to a standstill if this were the case.

The conflict surrounding the tribunal was flanked by an international rhetorical stand-off between Israel and Hezbollah. Israel, which had expressed its caution upon the new government being formed, regarding it as Hezbollahdominated, had been dissatisfied with a UN report it deemed too lax on the issue of Hezbollah's weapons. Hezbollah Secretary-General Hassan Nasrallah responded by upping the ante and insisting that Hezbollah was stronger than ever and capable of winning any military conflict with Israel. This acquired additional significance as the issue of border demarcation between Israel and Lebanon was being disputed at the time, with Lebanon claiming that Israel sought to deprive it of exploiting valuable oil and gas fields in the Mediterranean. In a televised speech, Hassan Nasrallah threatened Israel with retaliation if it were to attack any of Lebanon's oil refineries (as it had done during the 2006 war, causing a major oil spill along the Lebanese coast) or other installations. This prompted a harsh reply from Christian politicians, most notably from the head of the Lebanese Forces, Samir Geagea, to the effect that Nasrallah was not an

4 This pattern of argumentation, incidentally, is common for non-state groups seeking to disassociate themselves from a violent past. During interviews with members of the Egyptian Muslim Brotherhood in Cairo in 2011, this author repeatedly heard the violent episodes in the movement's past explained as "isolated acts of individuals" for which the group as a whole was not responsible. elected official and could not speak for Lebanon's institutions, much less threaten Israel with war.

Things were heated up further when at the end of July a UNIFIL convoy was attacked in the Southern Lebanese city of Sidon, wounding six French troops. Israel immediately accused Hezbollah of being responsible for the attack. The dispute with Israel was escalated again when on August 1, 2011 an Israeli Defense Forces patrol ventured on Lebanese territory; there was an ensuing exchange of fire, during which no one was injured. UN Special Representative for Lebanon, Michael Williams, warned that incidents such as this one were highly dangerous and carried the potential for escalating into a full-scale war within hours.

At the same time, Lebanese president Michel Sleiman was starting consultations geared towards restarting a National Dialogue, the last sessions of which had taken place in November 2010, immediately before the breakdown of the national unity government. The contentious issues had of course been Hezbollah's weapons and the STL. During the renewed consultations, it immediately became obvious that the March 14 camp was unwilling to begin any negotiations unless they focused exclusively on the topic of Hezbollah's arsenal. Under pressure on various fronts, both in the heated-up rhetorical volleys with Israel and internally, with mounting pressure to focus on the topic of its arms, Hezbollah representatives and spokespeople methodically responded by invoking the "people, army, resistance"-formula. This was perhaps a sign of the pressure hitting its mark, as Hezbollah apparently saw a growing need to legitimize its armed status. The chairman of Hezbollah's Executive Council, Hashim Safieddine, displayed Hezbollah's somewhat vindictive attitude in this regard when he said that the party had been successful in "imposing" this formula on all actors in Lebanon, and underlined that there was no going back on the issue since it had officially been adopted in the government's policy statement (Lebanese National News Agency 2011a). Speaking on the anniversary of the killing of more than a hundred unarmed refugees by Israeli shells in Qana, he also stressed that Hezbollah's weapons were essential for their deterrent nature. Without them, Israel would be free to attack and invade the country, and of taking over assets that were rightfully Lebanese, such as oil and gas fields. He was thus providing an up-to-date justification for Hezbollah keeping its weapons, in the context of current events. Simultaneously, Hezbollah was also forced to respond to allegations that it was supporting the Syrian regime and helping to crack down on the uprising in the neighboring country; spokespeople vehemently refused any such claims and accused the March 14 General Secretariat of intentionally leaking information to international news outlets in order to create the impression that Hezbollah was fighting rebels in Syria (The Daily Star 2011a).

It was only in mid-August that the STL actually lifted the confidentiality restrictions on its indictments and publicized the names of the four suspects. All prior debate about the indictments had been based on leaks to the press, while the court had ordered the names to be kept confidential. As soon as they were published, Hassan Nasrallah held another speech on TV discrediting the tribunal, saying it held no evidence whatsoever, and calling the accused "honorable members of 
the resistance" that did not even have to be investigated (Al Manar 2011a).

All the pressure building up on Hezbollah was increasingly making it look like it was reacting rather than dictating policy or, as had been the expectation, significantly changing Lebanon's domestic politics. In addition to the slowly brewing conflict between Hezbollah and Israel, Syria increasingly became embroiled in a civil war to the extent that it became dysfunctional as a source of support for Hezbollah. Iran continued to be under international pressure and to be faced by harsh economic sanctions, partly because of its backing for Hezbollah. All these factors rendered the party increasingly vulnerable, a fact that was of course not lost on the domestic opposition, which was seeking to exploit this to its advantage, for example by pressing for a National Dialogue on the party's weapons during a moment of relative weakness.

On November 30, 2011, reflecting Hezbollah's somewhat weakened position, the Lebanese cabinet voted to provide the funding for the STL that the tribunal's statutes required it to provide. The cabinet session on this issue had continued late into the night in a sign of the difficulty of reaching an agreement. Prime Minister Najib Mikati had made his political future depend on it by saying, ahead of the session, that he would resign if the cabinet failed to approve the funding. After the decision was reached, Hezbollah Secretary-General Hassan Nasrallah admitted outright that it had been taken against the party's will, and that he still regarded the Tribunal as unconstitutional, illegitimate and politically driven. He regretted the decision and said that Prime Minister Mikati had taken it "unilaterally," while thanking all ministers who had voted against the motion. Mikati, during a subsequent interview, sought to downplay the disagreement and stressed that it was Hezbollah's right as a political party to disagree and oppose the funding of the tribunal, and that he held no grudges as a result of this.

At the beginning of 2012, with the civil war in Syria continuing to escalate, allegations abounded in Lebanon: the March 14 camp was accusing Hezbollah of supporting the Syrian regime and of shelling Syrian towns close to the Lebanese border, something Hezbollah vehemently denied. Hezbollah representatives, on the other hand, accused the Future Movement of supporting the Syrian opposition and providing them with weapons. In an interview with the Saudi newspaper Al-Sharq Al-Awsat, an officer in the Free Syrian Army accused Hezbollah of supporting Syrian regime troops in areas such as house-to-house fighting, and of carrying out targeted assassinations of opposition figures for the Assad regime (Al-Sharq al-Awsat 2012). Hezbollah spokespeople denied the claims shortly afterwards, calling it false that Hezbollah had any "martyrs or wounded" in Syria, which notably did not exclude the possibility of Hezbollah units operating in the neighboring country (The Daily Star 2012). In the row over Hezbollah's weapons, Hassan Nasrallah had made a renewed offer of dialogue to the March 14 camp, insisting that he was not imposing any conditions, but ruling out that the party would lay down its weapons. This was promptly taken up by Samir Geagea, leader of the Lebanese Forces, who rejected the call for dialogue on the grounds that Hezbollah was in fact imposing preconditions by ruling out a dialogue on its arms. The situation thus continued to stall with no movement on the horizon. Nasrallah reiterated some willingness for compromise during a March 2012 speech, when he insisted that Hezbollah was prepared to talk about its weapons in the context of a "national defence strategy." Based on his and other party representatives' previous quotes on this issue, the development of such a strategy would have entailed the continuation of the status quo, with perhaps closer coordination between Hezbollah and the Lebanese Army.

During the spring of 2012, the situation appeared to grow calmer from Hezbollah's perspective. While the issue of its arms continued to be hotly and controversially debated, the immediate pressure from its political rivals for disarmament had relented. Also, it became apparent that the regime of Bashar Al-Assad in Syria was holding on to power and fighting the uprising at a bloody cost, making the scenario of its downfall and Hezbollah's subsequent weakening seem more remote. This was reflected in several speeches by Hezbollah leader Hassan Nasrallah, calling for a "political solution" to the crisis in Syria along the lines of a negotiated settlement with the opposition that would leave Assad in power. He also strongly voiced his support for the Syrian leader and appeared generally emboldened on the issue of the Syrian regime's and his own party's future.

As the year wore on, however, things began to grow tense again, with the election campaign of 2013 looming on the horizon and renewed battles over the electoral law to be adopted. Hezbollah was arguing for a law of proportional representation, which would "reveal each party's actual strength." March 14 refused to take up the proposal. ${ }^{5}$ More worryingly for Hezbollah, the conflict in Syria was now in full escalation and was continually threatening to seriously spill over into Lebanon. Secretary-General Nasrallah had to repeatedly appeal for calm, e.g. when a bus full of Lebanese Shi'i pilgrims returning from Iraq through Syria was kidnapped, leading to angry street demonstrations by Hezbollah supporters in Lebanon. Sure enough, soon there were armed clashes in Beirut between Future Movement and March 8-affiliated armed groups.

\section{Conclusions}

The above discussion has revealed that Hezbollah values its participation in Lebanon's democratic politics as a legitimating factor for retaining its weapons. Without this participation, it would merely be understood as a "terrorist group" and be put on funding and cooperation blacklists by European governments (to date, this is mostly the case in the United States). As long as it is also a legitimate political actor

5 At the time of writing, a proposal for an electoral law based on proportional representation for each sect and a single election district for the whole country was gathering support. Observers fear that this so-called "Orthodox Law" will increase sectarian divisions in the country. It is backed by a number of Christian parties as well as Hezbollah and Amal. The Future Movement's refusal to back this law as well as Prime Minister Mikati's announcement that he would hold the 2013 elections as scheduled and if necessary, based on the present electoral law, spell out the next heated political conflict for Lebanon. 
and even participates in Lebanon's government, it is easier to withstand this kind of political pressure. In the aftermath of the Hariri assassination in 2005, the cards in Lebanon's political game were being reshuffled, and Hezbollah's role was aggressively questioned by the March 14 camp. As long as the party felt relatively strong, i.e. enjoyed the full support of Syria and had not yet been officially implicated in the investigation into Hariri's murder, it did not hesitate to take up March 14's challenge and to bring politics to a halt in Lebanon. This happened in 2006 (withdrawal of ministers), 2007 (general strike followed by sit-in) and 2008 (violent confrontations with March 14 forces). When March 14 stayed defiant and continued to challenge Hezbollah, the Arab uprisings began and the Shia party started losing credibility (for its hypocritical backing of Assad's regime while supporting other Arab uprisings) and support (as the Assad regime increasingly came under pressure and was less able to provide political and logistical support to Hezbollah), Hezbollah grew increasingly cooperative. The party had to accept that the Lebanese government expressed support for the Special Tribunal for Lebanon despite its objections. This shows its dramatically reduced room for manoeuvre in Lebanese politics. It is the outcome of both Hezbollah's desire to stay part of the political structure, as well as its generally weakened position in a regional context.

\section{Bibliography}

Aboul-Enein, Youssef. 2005. "Hizballah. A discussion of its early formation." Infantry Magazine 94(3): 21-25.

Al Manar. 2011a. "Lebanese Hezbollah leader says Hariri tribunal indictment 'had no evidence'." BBC Monitoring International Reports.

2011b. "Lebanese 'resistance' setting new equations to confront Israel - MP." BBC Monitoring International Reports.

Al-Sharq al-Awsat. 2012. "Free Syrian Army officer says Iranians, Hezbollah backing Al-Asad forces." BBC Monitoring International Reports.

. 2011. "Nothing new' in Special Tribunal for Lebanon's indictment - Hezbollah source." BBC Monitoring International Reports.

Alagha, Joseph. 2006. The shifts in Hizbullah's ideology: religious ideology, political ideology, and political program. Amsterdam: ISIM.

Deeb, Lara. 2006. An enchanted modern: gender and public piety in Shi'i Lebanon. Princeton, NJ [u.a.]: Princeton University Press.

Hamzeh, A. Nizar. 2004. In the Path of Hizbullah. Syracuse, NY: Syracuse University Press.

Hinnebusch, Raymond. 1998. "Pax Syriana? The origins, causes and consequences of Syria's role in Lebanon." Mediterranean Politics 3(1): 137-160.

Lebanese National News Agency. 2011a. "Hezbollah official comments on defence strategy, 'need to keep weapons'." BBC Monitoring International Reports. 2011b. "Lebanon's Sa'd al-Hariri calls for 'national solution' to Hezbollah weapons." BBC Monitoring International Reports.

McAdam, Doug, Sidney Tarrow, and Charles Tilly. 2001. Dynamics of Contention. Cambridge [u.a.]: Cambridge Univ. Press.

Muhanna, Elias. 2011. "Saving Lebanon's Syrian-SaudiQatari-Turkish Initiative." Qifa Nabki. http://qifanabki. com/2011/01/19/syria-saudi-lebanon-2/ (Accessed January 24, 2013).

Norton, Augustus Richard. 2009. Hezbollah: A Short History. Princeton, NJ [u.a.]: Princeton University Press.

Ollaik, Rami, and Chaden Maalouf Najjar. 2012. La route des abeilles. Paris: Editions Anne Carrière.

Palmer Harik, Judith. 2007. Hezbollah: The changing face of terrorism. London [u.a.]: I.B. Tauris.

Qassem, Naim. 2005. Hizbullah (Hezbollah): The Story from Within. Saqi Books.

Saad-Ghorayeb, Amal. 2002. Hizbu'llah: politics and religion. London [u.a.]: Pluto Press. http://www.gbv.de/dms/subhamburg/347685730.pdf (Accessed April 14, 2010).

Samaan, Jean-Loup. 2007. Les métamorphoses du Hezbollah. Paris: Karthala Editions.

The Daily Star. 2011. "Hezbollah says Lebanese opposition misled media over role in Syrian crackdown." BBC Monitoring International Reports.

2012. "Lebanon's Hezbollah rejects claim of involvement in Syria." BBC Monitoring International Reports. 